\title{
Television Advertising Strategy and Customer Loyalty in Insurance Sector in Rwanda
}

\author{
Dr. Mudaheranwa Benjamin', Mutambuka Deo², Habimana Theogene², Habinshuti Patrice ${ }^{2}$ \\ ${ }^{1}$ Christian University of Rwanda, Kigali, Rwanda, East Africa \\ ${ }^{2}$ Regent University's Business Development Center, BDC Rwanda, East Africa
}

\begin{abstract}
How to cite this paper: Dr. Mudaheranwa Benjamin | Mutambuka Deo | Habimana Theogene | Habinshuti Patrice "Television Advertising Strategy and Customer Loyalty in Insurance Sector in Rwanda" Published in International Journal of Trend in Scientific Research and Development (ijtsrd), ISSN: 24566470, Volume-3 | Issue-4, June 2019, pp.98-102, URL: https://www.ijtsrd.c om/papers/ijtsrd23 601.pdf

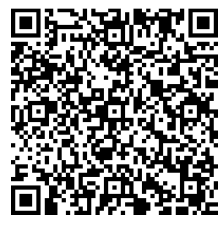
IITSRD23601
\end{abstract}

Copyright (C) 2019 by author(s) and International Journal of Trend in Scientific Research and Development Journal. This is an Open Access article distributed under the terms of the Creative Commons

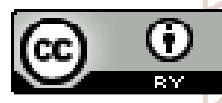

Attribution License (CC BY 4.0) (http://creativecommons.org/licenses/ by/4.0)

\section{ABSTRACT}

Customers are loyal because they believe that they receive superior products or commendable services and favorable treatment from their service providers, and also because they believe they don't have a better alternative. However, these customers may not be aware of the influence or impact that their service provider's advertisements really have on keeping them hooked or bowed to their brand and customer loyalty. The general objective of the study was to analyze the contribution of television advertising to customer loyalty in insurance sector in Rwanda. Specific objectives were to ascertain the determinants that influence customer loyalty in insurance sector in Rwanda, to assess the strategies related to advertisement undertaken by insurance companies on customer loyalty and to establish relationship between television advertisement and customer loyalty in insurance sector in Rwanda. The study design was descriptive-analytical design, the population of this research was from insurance companies' customers and employees and the sample size of the study was 98 people. The researcher used Statistical Packaging for Social Sciences (SPSS) as the statistical tool. The data was presented according to the research questions and research objectives. Tables were used to present data. Data from completed questionnaires were edited, categorized and entered into SPSS and summarized using the percentage of respondents for analysis. Inferential statistics (Pearson correlation coefficient was used to analyze data). This research used SPSS programm and found that the coefficient $r$ equal to 0.969 . According to Pearson, the correlation of 0.969 (96.9\%) is categorized as positive correlation and this leads to confirm that there is significant relationship between television advertisement and customer loyalty. This study recommended that, to enable meaningful participation, management should focus on advertisement, customer loyalty, and corporate strategy with carefully selected representatives for the skilled employees. Successful Brand loyalty in Rwandan insurance companies requires a strong skilled local leadership through a process of leadership development, community mobilization, capacity building, education, and conscious.

\section{KEYWORDS: Television, advertising, customer, loyalty, insurance sector}

\section{INTRODUCTION}

Advertising has been in existence for a very long time and can be traced back to the very beginnings of recorded history. Archaeologists working in the countries around the Mediterranean Sea dug up signs announcing various events and offers. The Romans painted walls to announce gladiator fights. During the Golden Age in Greece, town criers announced the sale of cattle, crafted items and even Cosmetics (Aydin \& Ozer, 2005). Today, advertising is widespread all over the world in different countries. But advertising trends vary from country to country. Cut throat competition and emergence of new marketing challenges only indicates the significant role of advertising, which is expected to play in the survival and growth of business units and insurance sector. The first television advertisement was broadcast in the United States at 14:29pm on July 1, 1941, when the Bolivia Watch Company paid $\$ 9$ to New York city NBC affiliate WNBT (now WNBC) for a 20 second spot shown before a baseball game between the Brooklyn Dodgers and Philadelphia Phillies (Udochi, 2013).

Latif (2011) also identified that advertisers need to understand what exactly would make Prospective or potential customers behave in the way that they would like. They also found that advertising may has the potential to contribute to brand choice among consumers. It is always costly to attract new customers, so the managers always try to find ways to retain their current customers and concentrate on different factors which enhances the customer loyalty among the customers of the organizations (Bilal, 2005), The $\$ 175$ billion U.S. auto insurance industry in United State of America (USA) could be spending its marketing dollars in more effective ways: targeting consumers based on needs rather than behavior; finding the optimal balance between retention and acquisition; and reaching shoppers with the right message at the right 
moment in their decision journey (McKinsey, 2012). According to Lin and Wang, (2006) two more factors which were mentioned in the loyalty model and could be considered in insurance sector are trust and commitment.

After the First World War, the Indian agencies failed because of the acute competition, mostly from the British and the American agencies. The Indian agencies had a tough time but could learn the importance of agency business as a rich source of employment and earnings. It made them to try the outdoor advertising media as many of the newspaper media were under the control of foreign agencies, during that period of scientific development serious attention was given by many agencies and organizations to various methods for testing the sales effectiveness of advertising strategy, media and copy, this was a new philosophy in the sense that it had meant subjecting the work of the creative man, the artist, the person who depended upon his own insights and intuition to some kind of performance yardsticks. As much as some three thousand years ago Papyrus sheets were used in Thebes in Egypt for announcing the reward for return of runaway slaves.The first advertisement was somewhat in the form of stenciled inscriptions. Which were found on earthen bricks prepared by the Babylonians about three thousand years before Christ (Adepoju \& Suraju, 2012).

Organizations have to communicate with their existing and potential customers about what they do. This, indeed, is a herculean task in Nigeria's insurance market environment due to its characteristic nature which is further encapsulated by the vagaries of Nigeria's economic, demographic, social, political, legal, religious, cultural and environmental forces. Marketing communication is very important and at the same time challenging in the insurance sub-sector. This is because the intangible natures of insurance services play a decisively challenging role in convincing customers as to value of insurance product. The marketing communication mix elements have become important players in the life of so many businesses (Idris, et al., 2012). Insurance is easily accessible for those in the developed world, but not for the poor due to exorbitant transaction costs which do not decrease in proportion to the value of the insurance policy. Insurance companies cannot simply write policies with values below a certain floor without pricing them unrealistically. A study by Access conducted in 2009 revealed that the rate of insurance penetration is less than $3 \%$ of GDP, with only $7 \%$ of the Kenyan population having any form of insurance (Karani, 2009).

According to Gordon (2008) relationship marketing and advertisement are not a wholly independent philosophy but draws on traditional marketing principles. This view suggests that the basic focus upon customer needs still applies, but that it is the way marketing is practiced that is changing, with a greater emphasis on customer value, establishing and maintain a relationship over a long period of time (Christopher \& Payne, 2005). If RM is indeed a descendant of traditional marketing then a good starting point in developing a definition of relationship marketing would be to look at how marketing has traditionally been perceived.

Insurance industry performance has improved since the adoption of new legislation in 2009. Further refinement of the regulatory regime was introduced to foster its development, including completion of the separation of life and non-life businesses, and revisions to capital, solvency and investment rules. Rwanda-specific mortality was developed to foster development of life insurance and annuity products.

In 2007, the Government of Rwanda developed a comprehensive and detailed insurance sector assessment plan based on the 2005 insurance sector assessment program (Ministry of Finannce and Economic Planning [MINICOFIN], 2013). The plan for the insurance sector reform focused on five areas; building financial structure infrastructure for instance legal framework, increasing access to finance mainly in rural sectors, strengthening the pension and insurance industry and developing the payment system.

\section{PROBLEM STATEMENT}

Customers are loyal because they believe that they receive superior products or commendable services and favorable treatment from their service providers, and also because they believe they don't have a better alternative. However, these customers may not be aware of the influence or impact that their service provider's advertisements really have on keeping them hooked or bowed to their brand and customer loyalty (Mcllroy\& Barnett , 2000). Therefore, on one hand advertising has lots of components and its resulting effects; on the other hand there are many factors which influence a customer's loyalty. The Rwanda Financial Sector Strategy is a long-term development strategy that governs the entire financial sector of Rwanda. It is obvious that the strategy will definitely help in the achievement of the financial sector objectives as set out in Vision 2020, Economic Development and Poverty Reduction Strategy (EDPRS II,) Seven years Government Program, and Strategy for Rwanda becoming an international service centre (Ministry of Finannce and Economic planning [MINICOFIN], 2013). A recent review of Rwanda's insurance sector highlighted that although the sector has made remarkable achievement, it still faces major challenges that need addressing to enable the financial sector to contribute meaningfully to the overall performance of the country's economy. The key challenges identified include; Rwanda's low savings rates as a result of low savings culture, limited access to insurance products and services, and low incomes that translates into low savings. Therefore, this research found out the contribution of television advertising to customer loyalty in insurance sector.

\section{OBJECTIVES OF THE STUDY}

The general objective of the study was to analyze if there is a contribution of television advertising to customer loyalty in the insurance sector in Rwanda Specific Objectives are:

I. To ascertain the determinants that influence customer loyalty in insurance sector in Rwanda;

II. To assess the strategies related to advertisement undertaken by insurance sector on customer loyalty;

III. To establish relationship between television advertisement and customer loyalty in insurance sector in Rwanda

\section{RESEARCH QUESTIONS}

I. What are the determinants that influence customer loyalty in insurance sector in Rwanda?

II. What are the strategies related to advertisement undertaken by insurance companies on customer loyalty? 
III. To what extent does television advertising is relate to customer loyalty in insurance sector in Rwanda?

\section{RELATED STUDIES}

Nha , André, and Gaston (2013) analyzed the mediating role of customer trust on customer loyalty in Canada. Mao, Customer Brand Loyalty (2010) assessed customer brand loyalty in China. Sri, Christina, and Tetty (2013) analyzed factors influencing customer loyalty toward online shopping in Indonesia. Mohammad, Seyyed, and Nima, (2013) analyzed Factors and elements influencing brand loyalty in Iran. Mukhiddin, Dileep and Jalal, (2012) analysed impact of relationship marketing on customer loyalty in the banking sector. Faizan (2011) analyzed the impact of customer satisfaction on customer loyalty and intentions to switch: evidence from banking sector of Pakistan. Ekrem, Hasan and Bünyamin (2007) analyzed effects of image and advertising efficiency on customer loyalty and antecedents of loyalty in Turkish. Ogechukwu (2012) analyzed if relationship marketing an acceptable marketing strategy to be used by anigerian commercial banks. Adepoju and Suraju (2012) analyzed the determinants of customer loyalty in Nigeria's GSM market. Yusuf ( 2014) analyzed determinants of customer loyalty among subscribers of global system for mobile (gsm) communication in north-western Nigeria. Kofi and Mark (2014) analyzed the influence of advertisement on customer loyalty in the telecommunications industry in Ghana. Arvinlucy, Moses, Isaac and Willis (2012) focused on implications of service quality on customer loyalty in the banking sector. Allan and Gordon (2014) analyzed factors influencing customer loyalty in telecommunication industry in Kenya.

Even though, other studies found that customers are loyal because they believe that they receive superior products or commendable services and favorable treatment from their service providers, and also because they believe they don't have a better alternative. Mcllroy and Barnett (2000) said that these customers may not be aware of the influence or impact that their service provider's advertisements really have on keeping them hooked or bowed to their brand and customer loyalty. Therefore, on one hand advertising has lots of components and its resulting effects; on the other hand there are should be many other factors which influence a customer's loyalty. The above studies focused on banking sectors and telecommunication industry, the reason why this study need to assess television advertising and customer loyalty in insurance sector in Rwanda using both descriptive and inferential statistics.

\section{RESEARCH METHODOLOGY}

The study design was descriptive-analytical design, this design mainly focused on both qualitative and quantitative approaches to a certain extent. Qualitative method was concerned with qualitative phenomena that relates to quality and kind, which include views, opinions, feelings, perceptions, and intentions of different respondents. Quantitative method was based on the measurement of quantity or amount, applicable to the phenomena that was expressed in terms of quantity, it allowed the researcher to focus on variables that was expressed mathematically which enabled researcher to analyze and get exact information required with minimum errors.

The population of this research was 5340 responds including 5215 insurance companies' customers and 125 employees.
The level of precision or sampling error was $10 \%$ and $90 \%$ confidence level, total population will be $\mathrm{N}=5340$, the sample size was calculated using the Yamane formula

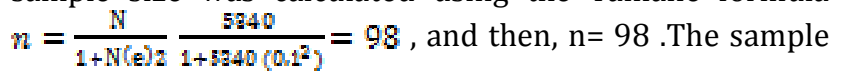
size of the study was 98 people. The researcher used SPSS as the statistical tool, this involved presenting findings in a logical and sequential way so that conclusions was drawn from them. The data was presented according to the research questions and research objectives. Tables were used to present data. Data from completed questionnaires were edited, categorized and entered into SPSS and summarized using the percentage of respondents for analysis. The data processed was analyzed according to the research objectives one by one with the consideration of the variable. The first and second research objectives were analyzed using descriptive statistics, whereas the third was analyzed used inferential statistics (Pearson correlation coefficient). The researcher did a pilot research, whereby, she used five employees from insurance companies and found that Croanbach Alpha was $0.90>0.7$, this confirmed that, the questionnaires were reliable.

\section{SUMMARY OF FINDINGS AND CONCLUSION}

According to the first research question, this study found that the determinants that influence customer loyalty in insurance sector in Rwanda are corporate social responsibility, corporate image, pressure of the form of legal regulation, degal protection of shareholders, board leadership structure, managerial risk, significant price, product differentiation, competition, sales promotion tool, consumer preferences, consumer buying behavior, product protection and add value of product. The study also concluded that, customer loyalty plays a more and more important role in the modern global marketing. In order to maximize profit, people try different strategies, among which, loyalty is recognized by a large amount of businessmen. On the other hand, some may assert that it is a challenge to achieve it.

According to the second research question, this research concluded that improvement of accountability is among of roles played by corporate image in insurance companies. Therefore, accountability is one of the cornerstones of corporate image; however, it can be difficult for practitioners alike to navigate the myriad of different types of accountability. Accountability ensures actions and decisions taken by public officials are subject to oversight so as to guarantee that companies initiatives meet their stated objectives and respond to the needs of the community they are meant to be benefiting, thereby contributing to better governance. Well-functioning legal institutions and governments bound by the rule of law in insurance were, in turn, vital to corporate image. Laws are not enforced, practitioners in the development field have increasingly turned their attention to reforms to improve legal and judicial institutions and promote the rule of law and corporate image.

According to the third research question, this research concluded that the strategies related to advertisement undertaken by insurance on customer loyalty are corporate reputation strategy, customer retention strategy, employees' retention strategy, product competitiveness at the market strategy, product innovation strategy, enhance product marketing strategy, company meet the market demand 
strategy and products development strategy. Corporate strategies improve governance. Therefore, through present research the researcher analyzed the statements regarding the corporate strategy in customer loyalty and concluded that corporate strategies represent all the approved policies and procedures used by the insurance management in order to achieve an effective management of customer. In relation to the relationship between television advertisement and customer loyalty using Pearson correlation coefficienty. This research used SPSS programm and found that the coefficient $r$ equal to 0.969 . According to Pearson, the correlation of $0.969(96.9 \%)$ is categorized as positive correlation and this leads to confirm that there is significant relationship between television advertisement and customer loyalty. In relation to the third research question, this study concluded that there was significant positive relationship between television advertisement and customer loyalty in insurance companies. Therefore, to build customer loyalty and sustain it, relationship television advertisement can play a key role to influence positively customers' perceptions of the organization and to enhance customer trust. Loyalty is not determined exclusively by the intrinsic characteristics of service offer. It can also depend on external traditional activities, such as advertising and public relations, well known to those in charge of marketing. So, the choice of elements for positioning and communication strategies must reflect the reality and ability of the organization to keep the promises of quality and benefit made to its customers in order to bridge the gap between action and rhetoric.

\section{RECOMMENDATIONS}

The study findings yielded the following recommendations in view of the contribution of television advertisement to the customer loyalty in insurance companies. To enable meaningful participation, management of insurance companies should focus on advertisement, customer loyalty, and corporate strategy with carefully selected representatives for the skilled employees. Successful Brand loyalty in Rwandan insurance companies requires a strong skilled local leadership through a process of leadership development, community mobilization, capacity building, education, and conscious.

\section{REFERENCES}

[1] Adepoju, A., \& Suraju, A. A.,. (2012). The Determinants of Customer Loyalty in Nigeria's Market Global System of Mobile Communications (GSM). International Journal of Business and Social Science, 3(14), PP.209 - 2012.

[2] Allan, S. N. K. \& Gordon, K. N. (2014). Factors Influencing Customer Loyalty In Telecommunication Industry In Kenya. International Journal of Social Sciences and Entrepreneurship(2), PP.14 - 29.

[3] Anderson \& Sullivan. (1993). The antecedents and consequences of consumer satisfaction for firms. . journal of Marketing Science, pp125-143.

[4] Arvinlucy, A. O., Moses, N. O., Isaac, O. \& Willis, 0. (2012). Implications of Service Quality on Customer Loyalty in the Banking Sector in Kenya. International Journal of Business and Social Science, 3(21), PP.223 233.

[5] Aydin.S \& Ozer.G. (2005). The analysis of antecedents of customer loyalty in the Turkish mobile telecommunication market. European Journal of Marketing, pp910-925.
[6] Bilal, A. (2005). Institute of Information Technology Abbottabad, Pakistan. Determinants of Customer Loyalty And Proposing A Customer Loyalty Model For The Banking Sector Of Pakistan.

[7] Bly, R. W. (2003). Proof Marketing. canada: Chafkin Max.

[8] Christopher, M. \& Payne, A. (2005). Relationship Marketing, Bringing Quality Customers Service and Marketing Together. Oxford England: Butterworth Heinemann.

[9] Ekrem, C., Hasan, A. \& Bünyamin, E.R. (2007). Effects Of Image And Advertising Efficiency On Customer Loyalty And Antecedents Of Loyalty In Turkish. Journal of Banks and Bank Systems, 2(1), PP.56 - 71.

[10] Faizan, M. ,. (2011). Impact of Customer Satisfaction on Customer Loyalty and Intentions to Switch: Evidence from Banking Sector of Pakistan. International Journal of Business and Social Science, 2(16), PP.263 - 267.

[11] Gordon, I. H. (2008). Relationship Marketing. Etobicoke Onatano Canada: John Wiley and Sons.

[12] Idris, A. A.,Asokere, A.S.,Ajemunigbohun, S. S.,Oreshile, A. S. \& Olutade, E. O. (2012). An Empirical Study of the Efficacy of Marketing Communication Mix Elements in Selected Insurance Companies in Nigeria. Australian Journal of Business and Management Research, 2(5), PP.08-18.

[13] Ivanovic, C. (2003). Dictionary of Marketing. Roma(italy): Bloomsbury.

[14] Jacob. (2005). "Why Some Customers are More Equal than others,. Determinants Of Customer Loyalty And Proposing A Customer Loyalty, pp215.

[15] Jamal\& Kamal .(2004). Customer satisfaction and retail banking . International Journal of Bank Marketing., pp146-160.

[16] Jones, Beatty,\& Mothersbaugh. (2002). Why customers stay: measuring the underlying dimensions of services switching costs and managing their differential strategic outcomes. Journal of Business Research, pp441-50.

[17] Karani, N. N. (2009). Challenges facing the uptake of Minsurance loyalty-based life insurance schemes: A case study of the yuCover micro-insurance scheme in Kenya. Egerton: Egerton University.

[18] Karlsson, L. (2007). Strategic Marketing. (4. Ed, Ed.) Principles and Practice of Marketing.

[19] Kofi, P \& Mark, K. A. (2014). The influence of advertisement on customer loyalty in the telecommunications industry in Ghana. Herald Journal of Marketing and Business Management, 3(1), PP. 022 033.

[20] Kon. (2004). Customer Churn, Stop it before it starts. Mercer Management Journal, pp54-60.

[21] Kotler, P. (2002). Marketing Management Millenium Edition. (T. Edition, Ed.) New Jersey: Prentice-Hall.

[22] Kotler,Armstrong,Saunders, \& Wong . (1999). Principles of Marketing. London: Perentice Hall Europe. 
[23] Latif A, Saleem S, AbideenZUl. (2011). Influence of Role Model on Pakistani Urban Teenager's Purchase Behavior. pp. 07-16.

[24] Mao, J. (2010). Customer Brand Loyalty. International Journal of Business and Management, 5(7), PP.213 217.

[25] McKinsey. (2012). Winning Share and Customer Loyalty in Auto Insurance.

[26] Mcllroy A\& Barnett S. (2000). Building Customer Relationships:Do discount cards work? . 10 (6),--. Managing service quality,10(6), pp:347.

[27] Ministry of Finannce and Economic planning [MINICOFIN]. (2013). Final Report Rwanda Financial Sector Strategy. Kigali, Rwanda: MINICOFIN.

[28] Mohammad, D., Seyyed, M., \& Nima, B. (2013). Factors and elements influencing brand loyalty: A case study in customers of Khazar gaz in Mazandaran. International Journal of Agriculture and Crop Sciences, 6(11), PP.712715.

[29] Mukhiddin, J., Dileep, M. \& Jalal, R. (2012). Impact Of Relationship Marketing On Customer Loyalty In The Banking Sector . Far East Journal of Psychology and Business, 6(3), PP. 36 - 55.

[30] Nha, N., André, L., \& Gaston, L. (2013). The Mediating Role of Customer Trust on Customer Loyalty.Journal of Service Science and Management, 6, PP.96-109.

[31] Ogechukwu, A. D. (2012). Is Relationship Marketing An Acceptable Marketing Strategy To Be Used By
aNigerian Commercial Banks? Universal Journal of Management and Social Sciences, 2(4), PP.27 - 54.

[32] Sri, A., P., Christina, L. \& Tetty, R. (2013). Factors Influencing Customer Loyalty Toward Online Shopping. International Journal of Trade, Economics and Finance, 4(3), PP. 104 - 110.

[33] Srinivasan, Anderson, \& Ponnavolu. (2007). Customer loyalty in e-commerce: an exploration of its antecedents and consequences. Journal of Retailing,, pp41-50.

[34] Swaminathan, V., Karen, L.P. \& Gürhan-Canli, Z. (2007). My' brand or 'our' brand: the effects of brand relationship dimensions and self-construal on brand evaluations. Journal of Consumer Research, 34(2), pp.248-259.

[35] Tim, A., Bhattacharya, C. B. \& Julie, E. (2012). Relating Brandand Customer Perspectives on Marketing Management. Journal Of Service Research, 5(1), PP.3-25.

[36] Walsh,Evanschitzky\& Wunderlich. (2008). Identification and analysis of moderator variables: Investigating the customer satisfaction-loyalty link. European Journal of Marketing,, pp977-1004.

[37] Yusuf, A. H. (2014). Determinants Of Customer Loyalty Among Subscribers Of Global System For Mobile (GSM) Communication In North-Western Nigeria. International Academic Conference Proceedings, PP.119 $-130$. 